\title{
EVALUATION OF COMPRESSIVE STRENGTH OF CEMENT USING RAYLEIGH'S DIMENSIONAL ANALYSIS APPROACH
}

\author{
Sunil Kute ${ }^{1}$, Kanchan Patil ${ }^{2}$, Rahul Salve ${ }^{3}$, Sanket Mandle ${ }^{4}$ \\ ${ }^{1}$ Professor, Department of Civil Engineering , K.K.Wagh Institute of Engineering Education \& Research Nashik, \\ (University of Pune)Maharashtra, India \\ ${ }^{2}$ Student, Department of Civil Engineering , K.K.Wagh Institute of Engineering Education \& Research Nashik, \\ (University of Pune) Maharashtra, India \\ ${ }^{3}$ Student, Department of Civil Engineering , K.K.Wagh Institute of Engineering Education \& Research Nashik, \\ (University of Pune) Maharashtra, India \\ ${ }^{4}$ Student, Department of Civil Engineering , K.K.Wagh Institute of Engineering Education \& Research Nashik, \\ (University of Pune) Maharashtra, India
}

\begin{abstract}
This paper presents the capability of Rayleigh's dimensional analysis approach to evaluate the compressive strength of cement .The destructive testing of cubes for evaluating compressive strength of cement is associated with the curing of 28 days .The period of 28 days put constraints on field schedules and hence there is a need to develop a mathematical model which can provide the accurate range of results based of previous data.

A mathematical model based on Lord Rayleigh's dimensional analysis approach provides concise and systematic way of evaluating the compressive strength of cement.A functional relationship of variables of cement is expressed in the form of an exponential equation which is dimensionally homogeneous. A dimensional constant is determined from the physical characteristics such as grade of cement, initial setting time and final setting time and the dimensionless parameters are then formed by grouping together the variables of like parameters. The validation of mathematical model is done with experimental results. The correlation coefficient is developed which indicates the best fitting of model results with experimental results
\end{abstract}

Keywords: Dimensional analysis, Rayleigh's method, Compressive strength of cement, Consistency, Setting time $* * *$

\section{INTRODUCTION}

Use of dimensional analysis in solving the different engineering problems is not a new approach. Makris,N. and Black, C.J., Dimitrakopoulos, E.G., et al ; Mavroeidis, G.P. and Dong,G. have used dimensional analysis in analyzing the problems related to seismic engineering [1,2,3]. Butterfield, R. has used the approach of dimensional analysis for geotechnical engineering problems [4]. Pathak,D.R. and Dhonde,H.B. have attempted to use the dimensional analysis in solving the problems related to reinforced concrete beams subjected to pure torsion and compressive strength of cement [5,6]. The literature shows that very few applications of dimensional analysis have been studied in the area of structural engineering. Moreover, it can be noticed that all the attempts in applying the dimensional analysis are based on Buckingham's $\pi$ theorem. The authors of present paper have not come across any literature reported on application of dimensional analysis using Rayleigh's method. Hence, this paper investigates the use of Raleigh's method of dimensional analysis in evaluating the compressive strength of cement.

\subsection{Methods of Dimensional Analysis}

Dimensional analysis is a mathematical technique which makes use of the study of dimensions as an aid to the solution of several engineering problems. It helps in determining a systematic arrangement of the variables in the physical relationship and combining dimensional variables to form non-dimensional parameter. There are two methods:-
i) Rayleigh Method
ii)Buckingham Pi Theorem

\subsubsection{Rayleigh Method}

This method of dimensional analysis was proposed by Lord Rayleigh in 1899, for determining the effect of temperature on the viscosity of gas. In this method, a functional relationship of some variables is expressed in the form of an exponential equation which must be dimensionally homogenous. Thus, if $\mathrm{x}$ is some function of variables $\mathrm{x}_{1}, \mathrm{x}_{2}, \mathrm{x}_{3} \ldots \ldots \mathrm{x}_{\mathrm{n}}$, the functional equation can be written in following general form.

$$
\mathrm{X}=\mathrm{f}\left(\mathrm{x}_{1}, \mathrm{x}_{2}, \mathrm{x}_{3} \ldots \mathrm{x}_{\mathrm{n}}\right)
$$

where $\mathrm{X}$ is dependent variable and $\mathrm{x}_{1}, \mathrm{x}_{2}, \mathrm{x}_{3} \ldots$ are independent variables. The basic equation then, can be written as

$$
\mathrm{X}=\mathrm{C}\left(\mathrm{x}_{1}{ }^{\mathrm{a}}, \mathrm{x}_{2}{ }^{\mathrm{b}}, \mathrm{x}_{3}{ }^{\mathrm{c}}, \ldots . \mathrm{x}_{\mathrm{n}}{ }^{\mathrm{n}}\right)
$$


where $\mathrm{C}$ is constant i.e. dimensionless number and $\mathrm{a}, \mathrm{b}, \mathrm{c}, \ldots . \mathrm{n}$ are arbitrary powers.

\subsubsection{Buckingham Pi Theorem}

The theorem states that if there are $\mathrm{n}$ variables (dependent and independent) in a dimensionally homogenous equation and if the variables contain ' $\mathrm{m}$ ' fundamental dimensions i.e. $[\mathrm{M}, \mathrm{L}, \mathrm{T}]$,then the variables are arranged into (m-n) dimensionless terms , the dimensionless terms are called $\pi$ terms.

\section{BASIC FORMULATION OF DIMENSIONAL}

\section{ANALYSIS USING RAYLEIGH'S METHOD}

Using Rayleigh's method of dimensional analysis, dependent variable is expressed as function of independent variables.

Hence,

$$
\begin{aligned}
V & =\left(S_{28}, \text { Si, Sf, } G, C\right) . \\
S_{28} & =f(C, S i, S f, G) \ldots .
\end{aligned}
$$

This basic equation can be written as;

$$
\mathrm{S}_{28}=\mathrm{K}\left(C^{a} S i^{b} S f^{c} G^{d}\right)
$$

where,

$\mathrm{S}_{28}=$ Compressive strength of cement at 28 days curing in $\mathrm{N} / \mathrm{mm}^{2}$

$\mathrm{K}$ is constant $=$ Dimensionless Number

$\mathrm{C}=$ Consistency of cement in percentage

$\mathrm{Si}=$ Initial setting time in minutes

$\mathrm{Sf}=$ Final setting time in minutes

$\mathrm{G}=$ Grade of cement in $\mathrm{N} / \mathrm{mm}^{2}$

Thus,

$$
\begin{aligned}
& \mathrm{S}_{28}=\mathrm{K} C^{a} \quad S i^{b} \quad S f^{c} \quad G^{d} \\
& \left(M^{1} L^{-1} T^{-2}\right)=\mathrm{K}(0)^{\mathrm{a}}\left(\mathrm{T}^{1}\right)^{\mathrm{b}}\left(\mathrm{T}^{1}\right)^{\mathrm{c}}\left(\mathrm{M}^{1} \mathrm{~L}^{-1} \mathrm{~T}^{-2}\right)^{\mathrm{d}} .
\end{aligned}
$$

For dimensional homogeneity; the exponents of each dimension on both sides of equation must be identical.

Thus,

For $\mathrm{M}, \mathrm{d}=1$

For $\mathrm{L}, \mathrm{d}=1$

For $\mathrm{T}, \mathrm{b}+\mathrm{c}-2=-2$

$\mathrm{b}+\mathrm{c}=0$

i.e. $(b=-c)$

putting these values in equation (5),

$$
\begin{array}{r}
\mathrm{S}_{28}=\mathrm{K}(S i)^{-c}(S f)^{c}(G) \\
\mathrm{S}_{28}=\mathrm{K}\left(\frac{S f}{S i}\right)^{c} \mathrm{G} \ldots \ldots \ldots \ldots \ldots \ldots \ldots \ldots \ldots \ldots
\end{array}
$$

The laboratory results are used to determine the constants for this model. The similar parameters of cement were investigated in laboratory and used in model.

\section{EXPERIMENTAL INVESTIGATION}

The laboratory tests were conducted on cement as per relevant I. S. code.53 grade cement was used for experimental investigations. The consistency of cement was adopted in the range of 27 to 28.7. Initial and final setting time was determined .The cube moulds of $7.06 \mathrm{~mm}$ size were cast with cement and cured for 28 days and tested in compression testing machine. Following are the results of experimental investigations on cement.

Table-1: Laboratory results of tests on cement

\begin{tabular}{|l|l|l|l|l|l|}
\hline $\begin{array}{l}\mathrm{Sr} \\
\mathrm{No} \\
\cdot\end{array}$ & $\begin{array}{l}\mathrm{G} \\
(\mathrm{Cemen} \\
\mathrm{t} \\
\text { grade }) \\
(\mathrm{N} / \\
\left.\mathrm{mm}^{2}\right)\end{array}$ & $\begin{array}{l}\mathrm{C} \\
\text { Consi } \\
\text { stenc } \\
\mathrm{y} \\
(\%)\end{array}$ & $\begin{array}{l}\text { Si } \\
\text { Initial } \\
\text { setting } \\
\text { time } \\
(\mathrm{min})\end{array}$ & $\begin{array}{l}\text { Sf } \\
\text { Final } \\
\text { setting } \\
\text { time } \\
(\mathrm{min})\end{array}$ & $\begin{array}{l}\text { S28 days } \\
\text { Compressiv } \\
\text { from strength } \\
\text { experimental } \\
\text { results } \\
\left(\mathrm{N} / \mathrm{mm}^{2}\right)\end{array}$ \\
\hline 1 & 53 & 28 & 195 & 285 & 64.7 \\
\hline 2 & 53 & 27.5 & 190 & 265 & 64 \\
\hline 3 & 53 & 28.25 & 205 & 300 & 64 \\
\hline 4 & 53 & 28.5 & 184 & 237 & 64.28 \\
\hline 5 & 53 & 28.5 & 184 & 247 & 64.4 \\
\hline 6 & 53 & 28 & 147 & 285 & 65.27 \\
\hline 7 & 53 & 28 & 190 & 285 & 64.7 \\
\hline 8 & 53 & 27.5 & 185 & 265 & 64.70 \\
\hline 9 & 53 & 27.5 & 135 & 285 & 66 \\
\hline 10 & 53 & 28.75 & 120 & 232 & 65.9 \\
\hline 11 & 53 & 28.75 & 120 & 275 & 66 \\
\hline 12 & 53 & 28.5 & 184 & 232 & 64.3 \\
\hline & & & & & \\
\hline
\end{tabular}

\section{VALIDATION OF MODEL}

Using above laboratory results, the constants are developed. Hence, adopting equation (7) as the trial model,

$$
\mathrm{S}_{28}=\mathrm{K}\left(\frac{S f}{S i}\right)^{c} \mathrm{G}
$$

The validation of model is done by putting value of $\mathrm{K}$ and $\mathrm{c}$ on trial and error basis. The value which provides the matching results with experimental value is selected as valid value of the constant in the model. It is observed that at $\mathrm{K}=1.195$ and $\mathrm{c}=0.059$, the results of experiments and that of mathematical model match with each other. Hence, these values are considered as valid values. 
Table-2: Trial and error with values of constants for equation

\begin{tabular}{|l|l|l|l|}
\hline Trial number & K & C & Remark \\
\hline 1 & 1.02 & 0.5 & Not valid \\
\hline 2 & 1.05 & 0.5 & Not valid \\
\hline 3 & 1.2 & 0.05 & Not valid \\
\hline 4 & 1.19 & 0.05 & Not valid \\
\hline 5 & 1.195 & 0.06 & Not valid \\
\hline 6 & 1.195 & 0.059 & Valid \\
\hline
\end{tabular}

Thus, putting these values in the model,

$$
\begin{aligned}
\mathrm{S}_{28} & =\mathrm{K}\left(\frac{S f}{S i}\right)^{c} \mathrm{G} \\
& =1.195\left(\frac{285}{195}\right)^{0.059} 53 \\
& =64.76 \mathrm{~N} / \mathrm{mm}^{2}
\end{aligned}
$$

The different values of 28 days compressive strength of cement were calculated using above model and then compared with experimental values. The coefficient of correlation in form of ratio of 28 days compressive strength by experimental approach to that of as calculated by dimensional analysis was derived and presented in Table-3

Table-3: Validation of experimental results with analytical

\begin{tabular}{|l|l|l|l|}
\hline $\begin{array}{l}\text { Sr. } \\
\text { No. }\end{array}$ & $\begin{array}{l}\mathrm{S}_{28} \quad \text { days } \\
\text { compressive } \\
\text { strength from } \\
\text { experimental } \\
\text { results } \\
\left(\mathrm{N} / \mathrm{mm}^{2}\right)\end{array}$ & $\begin{array}{l}\mathrm{S}_{28} \text { days } \\
\text { compressive } \\
\text { strength } \\
\text { calculated } \\
\text { using } \\
\text { dimensional } \\
\text { analysis } \\
\left(\mathrm{N} / \mathrm{mm}^{2}\right)\end{array}$ & $\begin{array}{l}\text { Correlation } \\
\text { Coefficient }\end{array}$ \\
\hline 1 & 64.7 & 64.76 & 0.9990 \\
\hline 2 & 64 & 64.59 & 0.99086 \\
\hline 3 & 64 & 64.77 & 0.98805 \\
\hline 4 & 64.28 & 640285 & 1.01 \\
\hline 5 & 64.4 & 64.444 & 1.01 \\
\hline 6 & 65.27 & 65.85 & 0.9910 \\
\hline 7 & 64.7 & 64.86 & 0.9974 \\
\hline 8 & 64.70 & 64.69 & 1.001 \\
\hline 9 & 66 & 66.18 & 0.997 \\
\hline 10 & 65.9 & 65.84 & 1.008 \\
\hline 11 & 66 & 66.51 & 0.992 \\
\hline 12 & 64.3 & 64.207 & 1.0046 \\
\hline & & & \\
\hline
\end{tabular}

\section{CONCLUSIONS}

The correlation factor was observed in the range of 0.998 to 1.01 which indicates the moderate matching of model results with experimental results. The prediction of compressive strength of cement is possible for the similar conditions in the data of initial setting time, final setting time and grade of cement is known. This saves the period of 28 days. Also,

facilitates to complete the project earlier which leads to economy of project.

\section{ACKNOWLEDGEMENTS}

The help rendered by Er. Rajendra Waghmode and Er. Chaintanya Pipada in experimental investigation is thankfully acknowledged.

\section{REFERENCES}

[1] Makris,N. and Black,C, J. , "Dimensional analysis of bilinear oscillators under pulse type excitations" ,Journal of Engineering Mechanics (ASCE)2004,130(9),pp1019-31.

[2] Dimitrakopoulos, E.G.;Markri.N;Kappos A.J.;'Dimensional analysis of pounding oscillators", Sixth GRACM international congress on computational mechanics, Thessaloniki,2008,19-21 June.

[3] Mavroeidis, G.; Dong, G, Papageorgiou, A.S;'Near fault ground motions and the response of elastic and inelastic single degree of freedom systems", Earthquake Engineering structural Dynamics, 2004, 33, pp 1023-49.

[4] Butterfield, R;'Dimensional analysis for geotechnical engineers", Journal of Geotechnique, 49(3), 1999, pp357-366

[5] Pathak, D.R. and Dhonde, H.B.;'Dimensional analysis of reinforced concrete beams subjected to pure tension", Journal of structural Engineering; 129(11), 2003, pp-1559-1563.

[6] Pathak, D.R and Dhonde, H.B;'Prediction of 28 days compressive strength of 53-grade cements using dimensional analysis “, Journal of Materials in Civil Engineering, ASCE,(17),2005 pp 733-735

\section{BIOGRAPHIES}

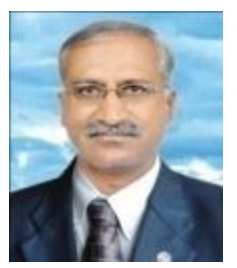

Dr.Sunil Kute: He is currently Professor of Civil Engineering. Also, he is chairman, Board of Studies (Civil Engineering) and member of Academic Council and Senate of University of Pune. He has experience of 23 years in teaching, administration and research. He is Ph.D. guide of University of Pune and North Maharashtra University. His 45 research papers are published in journals and conferences. His research areas are structural engineering and water resources engineering. Currently, 6 students are pursuing Ph.D. under his guidance.

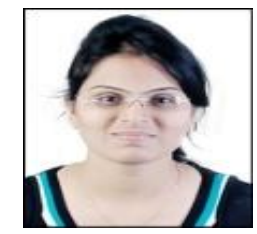

management.
Er. Kanchan Patil: She is pursuing her engineering studies at Department of Civil Engineering, K.K.W. Institute of Engineering Education and Research, Nasik. Her research area includes structural engineering and construction 


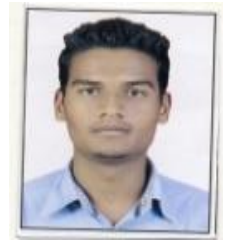

management.

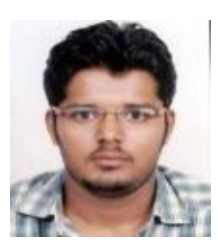

management.
Er.Rahul Salve: $\mathrm{He}$ is pursuing his engineering studies at Department of Civil Engineering, K.K.W. Institute of Engineering Education and Research, Nasik. His research area includes structural engineering and construction

Er.Sanket Mandle: $\mathrm{He}$ is pursuing his engineering studies at Department of Civil Engineering, K.K.W. Institute of Engineering Education and Research, Nasik. His research area includes structural engineering and construction 